\title{
Comparison between Cefoxitin Disc Diffusion and Phoenix Automated System with mecA/mecC PCR for Determination of Methicillin Resistance in Staphylococcus aureus Isolates and Investigation of the Presence of PVL Gene
}

\author{
Staphylococcus aureus Izolatlarında Metisilin Direncinin Belirlenmesinde Sefoksitin Disk \\ Difüzyon ve Phoenix Otomatize Sisteminin mecA/mecC PZR Yöntemi ile KarşılaştıııIması ve \\ PVL Gen Varlığının Araştıııması
}

\author{
(1) Neslihan ARICI ${ }^{1}$, (1) Banu BAYRAKTAR ${ }^{2}$ \\ 1 Üsküdar State Hospital, Laboratory of Clinical Microbiology, Istanbul, Turkey \\ 2University of Health Sciences, Şişli Hamidiye Etfal Training and Research Hospital, Clinic of Clinical Microbiology, Istanbul, Turkey
}

\section{Abstract}

Introduction: A fast and accurate determination of methicillin resistance in Staphylococcus aureus strains is vital. This study aimed to compare the sensitivity and specificity of the cefoxitin disc diffusion (CDD) test and BD Phoenix automated system considering mec $A / m e c C$ positivity as the gold standard and to investigate the presence of Panton-Valentine leukocidin $(P V L)$ toxin gene, a crucial virulence factor of $S$. aureus strains.

Materials and Methods: Overall, 179 Staphylococcus aureus strains from various clinical samples were included. Antibiotic sensitivity was tested using the Phoenix automated system and by applying the Kirby-Bauer disc diffusion method for cefoxitin ( $30 \mu \mathrm{g})$. The mec $A$, mecC, and $P V L$ presence was determined using the conventional multiplex polymerase chain reaction method. $\mathrm{mec} A / \mathrm{mec} C$ positivity was considered as the gold standard. Statistical analysis was performed using SPSS 15.0 for Windows (Chicago, IL, USA).

Results: Overall, 91 strains (50.8\%) were mecA positive and identified as methicillin resistant Staphylococcus aureus (MRSA). No isolates containing the mecC gene were detected. The Phoenix automated system falsely identified six methicillin-sensitive $S$. aureus (MSSA) isolates, which were mecA and mecC negative as MRSA. The sensitivity and specificity of the CDD test were found to be 100\% in determining MRSA, and the sensitivity and specificity the Phoenix automated system were $100 \%$ and $93.2 \%$, respectively. The PVL positivity rate in MRSA and MSSA strains was $6.5 \%$ and $7.4 \%$, respectively. All PVL-positive strains were isolated from the skin and soft tissues.

Conclusion: The CDD test is a reliable method for routine procedures. Methicillin-sensitive strains can be determined as MRSA via the Phoenix automated system. Nevertheless, mecC-controlled MRSA should not be excluded from methods used for determining methicillin resistance. PantonValentine leukocidin toxin gene should be determined to enable clinicians to understand the infection severity.

Keywords: $m e c A$, mecC, ORSA, Kirby-Bauer test, molecular epidemiology

Giriş: Staphylococcus aureus kökenlerinde metisilin direncinin hızlı ve doğru bir şekilde belirlenmesi hayati öneme sahiptir. Bu çalışmada, mecA/ mecC pozitifliği altın standart kabul edilerek, sefoksitin disk difüzyon (CDD) testinin ve BD Phoenix otomatize sisteminin duyarlılık ve özgüllüklerinin karşılaştırılması ve S. aureus kökenlerinin önemli bir virülans faktörü olan Panton-Valentine lökosidin (PVL) toksin geni varlığının araştırılması amaçlandı.

Gereç ve Yöntem: Çeşitli klinik örneklerden elde edilmiş toplam 179 S. aureus suşu çalışmaya dahil edildi. Antibiyotik duyarlılığı, Phoenix otomatize sistemi ve sefoksitin $(30 \mu \mathrm{g})$ için Kirby-Bauer disk difüzyon yöntemi uygulanarak test edildi. mec $A$, mecC ve $P V L$ genlerinin varlığı konvansiyonel

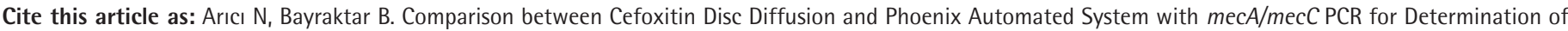
Methicillin Resistance in Staphylococcus aureus Isolates and Investigation of the Presence of PVL Gene. Mediterr J Infect Microb Antimicrob. $2019 ; 8: 33$. 
multipleks polimeraz zincir reaksiyonu yöntemi kullanılarak belirlendi. mecA/mecC pozitifliği altın standart olarak kabul edildi. İstatistiksel analiz için SPSS 15.0 (Chicago, IL, USA) for Windows programı kullanıldı.

Bulgular: mecA geni içeren doksan bir köken $(\% 50,8)$ metisiline dirençli Staphylococcus aureus (MRSA) olarak tanımlandı. mecC geni içeren hiçbir izolat tespit edilmedi. Phoenix otomasyon sistemi mecA ve mecC negatif olan altı metisiline duyarlı S. aureus (MSSA) izolatını yanlışıkla MRSA olarak tanımladı. MRSA'nın belirlenmesinde CDD testinin duyarlılığı ve özgüllüğü \%100, otomatize sistemin duyarlıığı ve özgüllüğü ise sırasıyla \%100 ve \%93,2 olarak bulundu. MRSA ve MSSA suşlarında PVL pozitifliği sırasıyla \%6,5 ve \%7,4 idi. Panton-Valentine lökosidin pozitif tüm suşlar deri ve yumuşak doku örneklerinden izole edildi.

Sonuç: Sefoksitin disk difüzyon testi, rutin prosedürde kullanılabilecek güvenilir bir yöntemdir. Metisiline duyarlı suşlar Phoenix sistemi ile metisiline dirençli saptanabilir. Metisilin direncinin belirlenmesinde kullanılan yöntemlerin mecC ilişkili MRSA'ları gözden kaçırmaması gerekir. PantonValentine lökosidin toksin geni, klinisyeni enfeksiyonun ciddiyeti konusunda uyarması açısından belirlenmelidir.

Anahtar Kelimeler: $m e c A, m e c C, O R S A$, Kirby-Bauer testi, moleküler epidemiyoloji

\section{Introduction}

Methicillin-resistant Staphylococcus aureus (MRSA) strains cause significant health problems worldwide, thereby warranting a fast and accurate method to determine methicillin resistance ${ }^{[1]}$. Methicillin resistance in Staphylococcus aureus lineages is associated with mutated penicillin-binding protein $2 \mathrm{a}$, which is coded by the mec $A$ gene ${ }^{[2]}$. However, after the discovery of a new mecA homolog gene (with 70\% nucleotide homology), named mecC(mecA-LGA251), the detection of mecA alone is not considered as the gold standard in determining methicillin resistance ${ }^{[3,4]}$. In various studies, animals like cows and sheep that were infected with MRSA containing mecC were identified as the new zoonotic source of infection for humans ${ }^{[5,6]}$. Since it was was impossible to detect this gene using the conventional and molecular methods employed to determine methicillin resistance through mec $A$, it was necessary to develop commercial and conventional polymerase chain reaction $(P C R)$ methods that determine both genes ${ }^{[7,8]}$.

Nevertheless, because all laboratories do not have access to molecular techniques, various phenotypic methods were used to determine methicillin resistance. Among these, the cefoxitin disc diffusion test (CDD, $30 \mu \mathrm{g}$, Oxoid, England) has been reported to be suitable in determining methicillin resistance by the Clinical and Laboratory Standards Institute $(\mathrm{CLSI})^{[9]}$, and supported by various publications ${ }^{[1,2,10]}$.

Furthermore, automatized diagnostic systems that are currently being used in several microbiology laboratories were investigated for their sensitivity in the determination of MRSA. A significant advantage of the automated system is that it saves time in identifying staphylococcal species and determining the methicillin resistance ${ }^{[11]}$.

Panton-Valentine leukocidin ( $P V L$ ) toxin, which is an important virulence factor of $S$. aureus, may cause serious necrotizing infections with high mortality (56\%-63\%) in healthy and young individuals ${ }^{[12]}$. Therefore, epidemiological studies uncovering the clonal spread of $S$. aureus strains in the hospital and community settings are crucial ${ }^{[13,14]}$.
In our study, by referencing mecA and mecC presence in $S$. aureus strains as the golden standard, we aimed to evaluate the performance of the CDD test and Phoenix automated system in accurately detecting MRSA, as well as contribute to the limited epidemiological data regarding isolates containing mecC. Moreover, we analysed the PVL toxin gene presence in these strains by using multiplex PCR.

\section{Materials and Methods}

Bacterial isolates: Overall, 179 S. aureus strains isolated from various clinical samples between January 2009 and October 2014 at our laboratory, which were kept at $-80{ }^{\circ} \mathrm{C}$ in Tryptic soy broth medium and were nonrecurrent (first sample of each patient), were included. Among these samples, 33.5\% were collected from clinics $(n=60), 25.1 \%$ from outpatients $(n=45), 18.5 \%$ from intensive care units $(n=33), 17.9 \%$ from the emergency room $(n=32), 3.9 \%$ from the hemodialysis unit $(n=7)$, and $1.1 \%$ from the burn unit $(n=2)$. Of all strains, $26.3 \%(n=47)$ were from blood cultures, 20.7\% $(n=37)$ from wound swabs, $14 \%(n=25)$ from abscesses, 8.4\% $(n=15)$ from bronchoalveolar lavage samples, 8.4\% $(n=15)$ from urine cultures, 5.6\% $(n=10)$ from biopsy samples, $3.9 \%(n=7)$ from catheter cultures, $3.9 \%$ $(n=7)$ from tracheal aspirates, 3.9\% $(n=7)$ from phlegm, 3.4\% $(n=6)$ from cerebrospinal fluid, $1.1 \%(n=2)$ from synovial fluid, and $0.6 \%(n=1)$ from peritoneal fluid.

Bacterial identification and antimicrobial susceptibility testing (AST): Bacteria were identified using matrix-assisted laser desorption-ionization-time of flight mass spectrometry (Bruker Biotyper, Germany). Methicillin resistance was determined using the CDD test (30 $\mu \mathrm{g}$, Oxoid, England) and automated system (Phoenix, Becton Dickinson, USA). The CDD test was studied and evaluated using the Kirby-Bauer disc diffusion method per the CLSI guidelines ${ }^{[9]}$. Evaluation of the the Phoenix System (Becton Dickinson, Sparks, MD) was performed based on the manufacturer's instructions.

Molecular detection of staphylococcal protein $\mathrm{A}$ (spa), mec $A$, mecC, and PVL genes: In our study, conventional multiplex PCR was used as the molecular method to determine spa, mecA, 
mecC, and PVL genes, as implemented by Stegger et al. ${ }^{[8]}$. For deoxyribonucleic acid (DNA) extraction, InstaGene Matrix (Bio$\mathrm{Rad}^{\circ}$, USA) was used. Two to three $S$. aureus colonies reproduced on sheep blood agar after a $24-h$ incubation at $37^{\circ} \mathrm{C}$ were added to $100 \mu$ l lysis buffer (InstaGene Matrix, Bio-Rad, USA), vortexed for $15 \mathrm{~s}$, and heated for $1 \mathrm{~h}$ at $56{ }^{\circ} \mathrm{C}$ on a heat block. After being reloaded in the vortex mixer, the sample was incubated for another hour at $95{ }^{\circ} \mathrm{C}$ and centrifuged at $13200 \mathrm{rpm}$ for 5 min. The supernatant was stored at $-20{ }^{\circ} \mathrm{C}$ for DNA sampling. Forward and reverse mixtures were prepared from spa, mec $A$, mecC, and $P V L$ primers (Table 1), and the product was added to the DreamTaq ${ }^{\text {TM }}$ Green PCR Master Mix (Thermo Scientific, Lithuania), which allows the product to be loaded to gel electrophoresis after amplification. The master mix was divided into $23-\mu \mathrm{l}$ aliquotes in PCR microtubes, and $2 \mu \mathrm{l}$ of extracted DNA product was put in each tube. For amplification, PCR cycles were configured to $5 \mathrm{~min}$ at $94{ }^{\circ} \mathrm{C}$ for outset denaturation, followed by 30 cycles for $30 \mathrm{~s}$ at $94^{\circ} \mathrm{C}, 1 \mathrm{~min}$ at $58^{\circ} \mathrm{C}, 1 \mathrm{~min}$ at 72 ${ }^{\circ} \mathrm{C}$, and finally $10 \mathrm{~min}$ at $72{ }^{\circ} \mathrm{C}$ for the ultimate elongation. The PCR product obtained was set in gel electrophoresis at $130 \mathrm{~V}$ for 60 min. The results revealed 162 base pair (bp) DNA fragments as mecA-positive, $138 \mathrm{bp}$ fragments as mecC-positive, and 85 bp fragments as $P V L$-positive. Deoxyribonucleic acid fragments between 180 and 600 bp in different sizes based on the strain were considered as spa. In the study, S. aureus American Type Culture Collection (ATCC) 29213 mecA (-), S. aureus mecC (+) Culture Collection University of Gothenburg (CCUG) 63582, S. aureus ATCC 49476 mecA (+), and S. aureus ATCC 49775 PVL (+) were used as control strains (Figure 1).

\section{Statistical Analysis}

Descriptive statistics were calculated as count and percent. McNemar test was used for comparison of the dependent proportions, and the Pearson chi-square test was employed for comparison of the independent proportions. The agreement between the protocols used in the study was evaluated using the Kappa coefficient. Moreover, the sensitivity and specificity of methods and their positive (PPV) and negative (NPV) predictive values were calculated. The statistical significance level was accepted as $p<0.05$. All the statistical methods were performed using Statistical Package for the Social Sciences version 15.0 for Windows (SPSS Inc., Chicago, IL, USA).

Ethics committee approval was obtained for this study from the Ethics Committee of Şişli Hamidiye Etfal Training and Research Hospital (protocol no: 14.01.2013/280). Informed consent was not received.

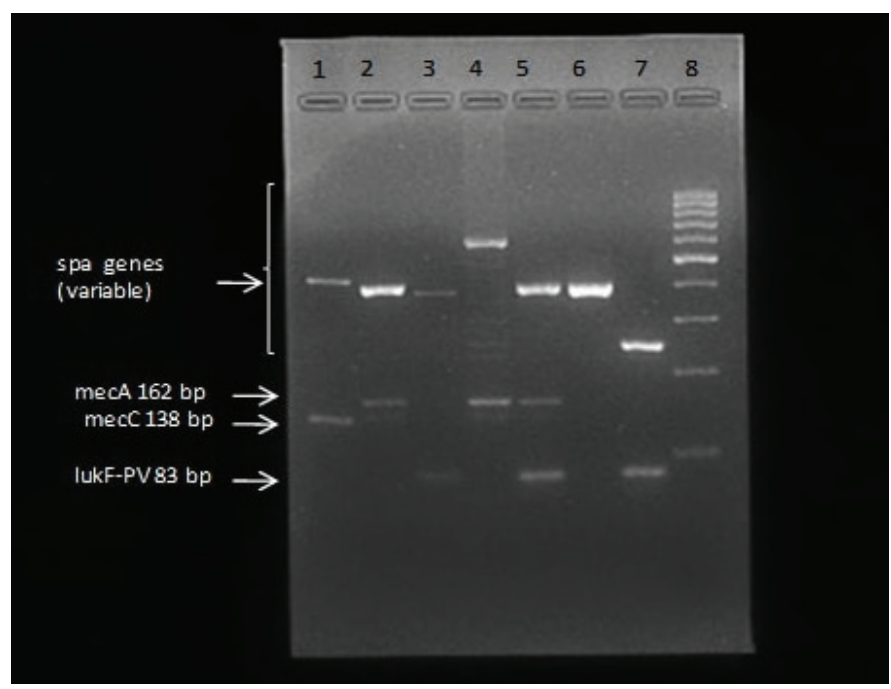

Figure 1. Gel electrophoresis of staphylococcal protein A (spa) mecC, mecA and Panton-Valentine leukocidin (PVL) genes by multiplex polymerase chain reaction.

Lane 1: mecC (+) S. aureus CCUG 63582 (138 bp).

Lane 2: mecA (+) S. aureus ATCC 49476 (162 bp).

Lane 3: PVL (+) S. aureus ATCC 49775 (85 bp).

Lane 4: $\operatorname{mec} A(+)$ S. aureus.

Lane 5: mecA (+), PVL (+) S. aureus.

Lane 6: mecA (-) S. aureus.

Lane 7: mecA (-), PVL (+) S. aureus.

Lane 8: 100 bp DNA marker.

ATCC: American Type Culture Collection, CCUG: Culture Collection University of Gothenburg, S. aureus: Staphylococcus aureus, bp: Base pair

Table 1. The primer sequences and expected amplicon sizes of each gene investigated using polymerase chain reaction in this study

\begin{tabular}{|c|c|c|c|c|}
\hline Gene name & Primer name & Sequence & Amplicon size (bp) & References \\
\hline \multirow[b]{2}{*}{ spa } & spa-1113F & 5' - TAAAGACGATCCTCGGTGAGC - 3' & \multirow[t]{2}{*}{$180-600$} & \multirow{2}{*}{ Stegger et al. ${ }^{[8}$} \\
\hline & spa-1514R & 5' - CAGCAGTAGTGCCGTTGCTT - 3' & & \\
\hline \multirow[b]{2}{*}{ mec $A$} & mecA P4 & 5' - TCCAGATACAACTTCACCAGG - 3' & \multirow[t]{2}{*}{162} & \multirow{2}{*}{ Stegger et al. ${ }^{[8}$} \\
\hline & mecA P7 & 5' - CСАCTTCATATCTTGTAACG - 3' & & \\
\hline \multirow[b]{2}{*}{$P V L$} & $P V L-F$ & 5' - GCTGGACAAAACTTCTTGGAATAT - 3' & \multirow[t]{2}{*}{85} & \multirow{2}{*}{ Stegger et al. ${ }^{[8}$} \\
\hline & $P V L-R$ & 5' - GATAGGACACCAATAAATTCTGGATTG - 3' & & \\
\hline \multirow[b]{2}{*}{ mecC } & $m{ }^{2} A_{\text {LGA251 }}$ MultiFP & 5' - GAAAAAAAGGCTTAGAACGCCTC - 3' & \multirow[t]{2}{*}{138} & \multirow{2}{*}{ Stegger et al. ${ }^{[8}$} \\
\hline & $m{ } A_{L_{G A} 251}$ MultiRP & 5' - GAAGATCTITCCGTITCAGC - 3' & & \\
\hline
\end{tabular}

bp: Base pair, PVL: Panton-Valentine leukocidin 


\section{Results}

Based on $\operatorname{mec} A / \operatorname{mecC}$ presence, $50.8 \%(n=91)$ of the isolates were MRSA and $49.2 \%(n=88)$ were methicillin-sensitive $S$. aureus (MSSA). All isolates determined to be mecA-positive through PCR were also determined to be resistant when tested using the CDD method. The Phoenix automated system falsely identified six MSSA isolates as MRSA, and it was statistically significant $(p=0.031)$ (Table 2). Moreover, these six MSSA isolates were determined to be resistant by using the CDD test. Considering $\operatorname{mec} A / \operatorname{mecC}$ positivity as the gold standard, the sensitivity, specificity, PPV, and NPV were 100\% for the CDD method and 100\%, 93.2\%, 93.8\%, and 100\%, respectively, for the Phoenix automated system (Table 3).

Among the 179 S. aureus strains that were included, 12 PVLpositive strains were detected, of which six were from MRSA strains and six from MSSA strains. Based on this data, the PVL positivity rate was found to be $6.5 \%$ among MRSA and $7.4 \%$ among MSSA. MRSA strains were isolated from the skin and soft tissue samples, including abscesses, wounds, and biopsy samples. PVL-positive MRSA strains were collected from patients hospitalized under the following services: orthopedics, otorhinolaryngology, general surgery, pediatric surgery, pediatric oncology, and pediatric infectious diseases. All PVLpositive MSSA strains were isolated from the skin and soft tissue samples of outpatients. Notably, no strains with mecC were detected among the MRSA and MSSA strains.

Table 2. Number of methicillin-resistant Staphylococcus aureus, methicillin-sensitive Staphylococcus aureus strains and percentages determined using cefoxitin disc diffusion and Phoenix automated sytem

\begin{tabular}{|c|c|c|c|c|c|c|}
\hline & \multicolumn{5}{|c|}{ mecA/mecC PCR } & \multirow[b]{3}{*}{ p } \\
\hline & \multicolumn{2}{|c|}{ MRSA } & \multicolumn{3}{|c|}{ MSSA } & \\
\hline & & $\mathbf{n}$ & $\%$ & $n$ & $\%$ & \\
\hline \multirow[t]{2}{*}{ CDD } & MRSA & 91 & 100 & 0 & 0.0 & 1.000 \\
\hline & MSSA & 0 & 0.0 & 88 & 100 & \\
\hline \multirow[t]{2}{*}{ Phoenix } & MRSA & 91 & 93.8 & 6 & 6.2 & 0.031 \\
\hline & MSSA & 0 & 0.0 & 82 & 100 & \\
\hline
\end{tabular}

MRSA: Methicillin-resistant Staphylococcus aureus, MSSA: Methicillin-sensitive Staphylococcus aureus, CDD: Cefoxitin disc diffusion, PCR: Polymerase chain reaction

Table 3. Sensitivity, specifity, positive predictive value, and negative predictive value rates for cefoxitin disc diffusion and Phoenix automated system

\begin{tabular}{l|c|c|c|c}
\hline & Sensitivity & Specificity & PPD & NPD \\
\hline CDD & 1,000 & 1,000 & 1,000 & 1,000 \\
\hline Phoenix & 1,000 & 0,932 & 0,938 & 1,000
\end{tabular}

PPV: Positive predictive value, NPV: Negative predictive value, CDD: Cefoxitin disc diffusion

\section{Discussion}

Considering the multiple antibiotic resistance in MRSA, it becomes imperative to rapidly and accurately ascertain methicillin resistance to choose the appropriate antibiotic therapy ${ }^{[15]}$. MRSA isolates falsely identified as sensitive may cause treatment failures, whereas MSSA isolates incorrectly identified as resistant may cause unnecessary glycopeptide antibiotic use, toxic effect exposure, and increased treatment $\operatorname{costs}^{[2]}$

In 2011, a new gene homolog named mecC on SCCmec XI (staphylococcal cassette chromosome mec) element was detected in human and bovine MRSA isolates ${ }^{[15]}$. After this discovery, several publications stated that detecting mecA alone cannot be considered to be the golden standard in the determination of methicillin resistance ${ }^{[3,4,16,17]}$. Several European countries started retrospective research on mecC positive MRSA isolates that could not be detected using mecA-based molecular methods. In a study conducted in Spain between 2008 and 2013 , overall, seven $(0.1 \%)$ strains containing mecC were determined among the study strain ${ }^{[18]}$. When $\operatorname{mecC}(+)$ MRSA was detected in a hospitalized patient in Slovenia, 395 community-origin MRSA isolates were scanned retrospectively between 2006 and 2013, and six more mecC (+) MRSA isolates were detected ${ }^{[19]}$. In a prospective study conducted in England by Paterson et al. ${ }^{[20]}$, nine mecC-positive isolates were detected among 2010 MRSA strains, and the prevalence was $0.45 \%$. A study by Basset et al. ${ }^{[7]}$ in Switzerland reported only one isolate $(0.06 \%)$ carrying this gene, whereas a study conducted in the USA ${ }^{[21]}$ detected no mecC-positive strains. Notably, only few studies are available regarding mecC in Turkey, and no MRSA strains were reported to carry this gene ${ }^{[22,23]}$. In a seven-year retrospective study by Kilıc et al. ${ }^{[22]}$, overall, 1700 S. aureus isolates comprising 1177 MSSA and 523 MRSA strains were screened for mecC, while no mecCpositive strains were found. They suggested that considering the regional epidemiological data in Turkey can rapidly change, multicenter studies should be conducted. In a recent multicenter study conducted by Cikman et al. ${ }^{[23]}, 494$ MRSA strains isolated from seven geographical regions in Turkey were investigated, and no mecC-positive strains were detected. Similarly, we did not observe any mec $C$-positive isolates among the $179 \mathrm{~S}$. aureus strains, of which 91 were MRSA and 88 were MSSA. The number and percentages of mecC-harboring $S$. aureus strains detected in various studies worldwide are presented in Table 4. Our study significantly contributes to mecC epidemiology in Turkey. However, considering worldwide studies, we believe that the number of strains included in our study was limited, and therefore, extensive studies are warranted to obtain the prevalence data in Turkey. 
Molecular-based methods are the golden standards in the determination of methicillin resistance, but every laboratory does not have the required facilities ${ }^{[10]}$. Therefore, more feasible and cheaper phenotypic methods were developed over the years. In a study by Panda et al. ${ }^{[24]}$ on CDD, which is one of the phenotypic methods, the sensitivity was determined to be $96.7 \%$ and specificity $100 \%$. In a study conducted by Iraz et al. ${ }^{[25]}$ in Turkey, the sensitivity and specificity of the disc diffusion method were $96.5 \%$ and $98.4 \%$, respectively. In another study by Uzun et al. ${ }^{[2]}$, these values were $98.3 \%$ and $100 \%$, respectively. On the other hand, in a study by Kriegeskorte et al. ${ }^{[26]}$ that included 111 mecC-positive $S$. aureus strains, CDD and oxacillin broth microdilution methods were used, and the sensitivity of these tests was determined to be $100 \%$ and $61.3 \%$, respectively. They concluded that the results emphasized the superiority of cefoxitin in the determination of even the mecC MRSA. The sensitivity and specificity results of various studies regarding the CDD test and Phoenix automated system are presented in Table 5. In our study, the sensitivity and specificity of the CDD method were both $100 \%$. Hence, we consider CDD to be an accurate test for determining mecA-mediated resistance in $\mathrm{S}$. aureus that can be employed as an alternative to PCR in resource constraint laboratories.

Automated diagnostic systems that are currently used in several microbiology laboratories have adapted their products to optimize the detection of mecA-mediated resistance. The Phoenix system offers panels that include both oxacillin and cefoxitin-as an improvement from the initial version. The instrument's expert system interprets any $S$. aureus isolate that

Table 4. Number and percentages of mecC-harboring methicillin-resistant Staphylococcus aureus strains detected in different studies

\begin{tabular}{l|l|l|l}
\hline References & Country & $\begin{array}{l}\text { Total number of } \\
\text { S. aureus isolates }\end{array}$ & $\begin{array}{l}\text { mecC- } \\
\text { MRSA } \\
\text { (n; \%) }\end{array}$ \\
\hline Garcia-Garrote $^{[18]}$ & Spain & 5502 & $7 ; 0.1 \%$ \\
\hline Paterson $^{[20]}$ & England & 2010 & $9 ; 0.45 \%$ \\
Ganesan $^{[21]}$ & USA & 102 & $0 ; 0 \%$ \\
Basset $^{[7]}$ & Switzerland & 1617 & $1 ; 0.06 \%$ \\
Kılıc $^{[22]}$ & Turkey & 1700 & $0 ; 0 \%$ \\
CIkman $^{[23]}$ & Turkey & 494 & $0 ; 0 \%$ \\
\hline
\end{tabular}

MRSA: Methicillin-resistant Staphylococcus aureus is tested positive by the cefoxitin screen (MIC $>4 \mu \mathrm{g} / \mathrm{ml}$ ) to be oxacillin resistant. Mencacci et al. ${ }^{[27]}$ tested the performance of this system with 1066 S. aureus strains and determined its sensitivity and specificity to be $100 \%$ and $99.8 \%$, respectively. In a study by Junkins et al. ${ }^{[28]}$, the sensitivity and specificity of the Phoenix automated system were determined to be $99.8 \%$ and $100 \%$, respectively. A study in Turkey by Cekin et al. ${ }^{[11]}$ compared the determination of methicillin resistance of 206 S. aureus isolates by using the Phoenix automated system and real-time PCR. They observed that the sensitivity and specificity were both $100 \%$, and based on these results, they concluded that the automated system was a practical and reliable method that can be used in routine microbiology laboratories. Iraz et al. ${ }^{[25]}$ determined the sensitivity and specificity of the automated system to be $98.8 \%$ and $97.6 \%$, respectively. In our study, the Phoenix automated system falsely identified six mecA-negative MSSA isolates as MRSA. Based on this data, the sensitivity and specificity of the automated system were 100\% and 93.2\%, respectively. Our results were in concordance with the other studies, revealing that the sensitivity of automated systems is high, and their specificity is relatively low. Notably, falsepositive detection of resistance results in unnecessary use of glycopeptides, particularly vancomycin. Consequently, such an increase in glycopeptide usage may increase vancomycinintermediate $S$. aureus and vancomycin-resistant $S$. aureus strains. Therefore, it is recommended to determine the presence of $m e c A / m e c C$ genes through molecular tests in the strains that are identified as MRSA by the automated system, and if this is impossible, the CDD test should be performed. Even

Table 6. Percentages of Panton-Valentine leukocidin-positive methicillin-resistant Staphylococcus aureus and methicillinsensitive Staphylococcus aureus strains detected in different studies

\begin{tabular}{l|l|l}
\hline References & $\begin{array}{l}\text { PVL-positive } \\
\text { MRSA (\%) }\end{array}$ & $\begin{array}{l}\text { PVL-positive } \\
\text { MSSA (\%) }\end{array}$ \\
\hline Kilic $^{[22]}$ & $1.7 \%$ & $1.9 \%$ \\
\hline Demirr & $0 \%$ & $9.1 \%$ \\
Gulmez $^{[3]]}$ & $0 \%$ & $2.2 \%$ \\
Hu $^{[14]}$ & $28.6 \%$ & No data \\
van der Mee-Marquet $^{[30]}$ & $33.8 \%$ & No data \\
\hline
\end{tabular}

PVL: Panton-Valentine leukocidin, MRSA: Methicillin-resistant Staphylococcus aureus, MSSA: Methicillin-sensitive Staphylococcus aureus

Table 5. Sensitivity and specificity results of cefoxitin disk diffusion test and Phoenix automated system in different studies

\begin{tabular}{|c|c|c|c|c|c|}
\hline & \multicolumn{2}{|c|}{ CDD test } & \multicolumn{3}{|c|}{ Phoenix automated system } \\
\hline References & Sensitivity & Specifity & Reference & Sensitivity & Specifity \\
\hline Panda ${ }^{[24]}$ & $96.7 \%$ & $100 \%$ & Junkins $^{[28]}$ & $99.8 \%$ & $100 \%$ \\
\hline Uzun $^{[2]}$ & $98.3 \%$ & $100 \%$ & $\operatorname{Iraz}^{[25]}$ & $98.8 \%$ & $97.6 \%$ \\
\hline
\end{tabular}

CDD: Cefoxitin disk diffusion 
though automated systems are frequently used in routine laboratories for AST owing to their ease of use, there is negligible evidence regarding their ability to classify mecC-positive MRSA accurately ${ }^{[29]}$. A study by Kolenda et al. ${ }^{[29]}$ compared three automated AST systems regarding their ability to detect a large number of mecC-MRSA isolates $(n=111)$ and observed that the phenotypic detection rate for mecC-MRSA by using the Phoenix system was low at 75\%, while they concluded that this automated system might fail to detect mecC-encoded methicillin resistance. Kriegeskorte et al. ${ }^{[26]}$ investigated the accuracy of the Phoenix system in determining mecC-positive $S$. aureus strains and recommended that the categorization as methicillin-susceptible by using the AST systems should be verified using the molecular assays or CDD.

The risk of the prevalent $P V L$-positive healthcare-associated MRSA (HA-MRSA) strains is a serious concern that can result in the emergence of multidrug-resistant HA-MRSA isolates with increased virulence ${ }^{[13,14]}$. A study by Hu et al. ${ }^{[14]}$ reported the PVL positivity rate among MRSA strains to be $28.6 \%$. In another study by van der Mee-Marquet et al. ${ }^{[30]}$, this rate was determined to be $33.8 \%$. However, in studies conducted in Turkey, the rate ranged from $0 \%$ to $2 \%{ }^{[22,31,32]}$. Kılıc et al. ${ }^{[22]}$ determined 9 of 523 (1.7\%) MRSA isolates and 23 of 1177 (1.9\%) MSSA isolates as PVL-positive. In a study by Demir et al. ${ }^{[31]}, 22$ of $165(9.1 \%)$ MSSA isolates were PVL-positive, whereas none of the 77 MRSA isolates carried this gene. Similarly, in the study by Gülmez et al. ${ }^{[32]}$, no $P V L$-positive strains were detected among the MRSA strains, and the positivity rate was 2.2\% among the MSSA isolates. Percentages of PVL-positive MRSA and MSSA strains detected in different studies are presented in Table 6. In our study, the PVL positivity rate was 6.5\% among the MRSA and 7.4\% among the MSSA strains. The $P V L$ positivity rate among MSSA strains, which varied between $2 \%$ and $9 \%$ in studies conducted in Turkey, is compatible with our results. However, the rate of $P V L$-positive MRSA strains, which was found to range between $0 \%$ and $2 \%$ in other studies, is lower than our result. Similarly, in our study, all PVL-positive isolates were obtained from the skin and soft tissue samples, as reported in some other studies $^{[14,31,32]}$. Moreover, it was remarkable that all PVL-positive MRSA strains were isolated from inpatients while all $P V L$-positive MRSA strains were isolated from outpatients. However, we did not classify $S$. aureus strains according to the Center for Disease Control and Prevention criteria of whether they were hospital or community-acquired and the lack of mortality data for patients with PVL-positive $S$. aureus growth can be considered as some of the shortcomings of this study.

Nonetheless, this study had several additional limitations. The sample size for detecting mecC-harboring MRSA was ralatively small. On the other hand, we did not investigate the mecB gene in S. aureus isolates by using PCR. In addition, we did not perform the origin analysis of these strains by using the Pulsedfield gel electrophoresis method.

\section{Conclusion}

We conclude that the CDD method is easy to apply and reliable. Thus, it is suitable for routine laboratory use to determine mecAcontrolled methicillin resistance in $S$. aureus. Furthermore, we suggest confirming the Phoenix automated system findings by using an additional method, such as CDD. Despite low prevalence (0.06\%-0.5\%), mecC should not be overlooked, particularly in cases where MRSA is unresponsive to treatment, and molecular methods used to detect this gene should be more frequently included in laboratory research in Turkey.

\section{Acknowledgement}

We would like to thank Associate Professor, Onur Karatuna (Acıbadem Mehmet Ali Aydınlar University, Turkey), for contributing to our study by providing the standard strains.

Ethics

Ethics Committee Approval: Ethics committee approval was received for this study from the Ethics Committee of Şişli Hamidiye Etfal Training and Research Hospital (No: 14.01.2013/280).

Informed Consent: Informed consent was not received since this was a retrospective bacteriological strain based study.

Peer-review: Externally and internally peer-reviewed.

\section{Authorship Contributions}

Concept: NA, BB, Design: NA, BB, Data Collection or Processing: $N A, B B$, Analysis or Interpretation: NA, BB, Literature Search: NA, BB, Writing: NA.

Conflict of Interest: No conflict of interest was declared by the authors.

Financial Disclosure: The authors declared that this study received no financial support.

\section{References}

1. Hortac E, Evren E, Altunay F, Kuyucu U, Ergen 0. Investigation of Methicillin Resistance in Staphylococcus aureus Isolates by Using Disc Diffusion, Chromogenic Media, Gradient Diffusion Test, Oxacillin Agar Screening Methods. Türk Mikrobiyol Cem Derg. 2016;46:40-6.

2. Uzun B, Karataş Şener AG, Güngör $S$, Afşar I, Yüksel Ergin O, Demirci M. Comparison of Cefoxitin Disk Diffusion Test, Automated System and Chromogenic Medium for Detection of Methicillin Resistance in Staphylococcus aureus Isolates. Mikrobiyol Bul. 2013;47:11-8.

3. Becker K, Larsen AR, Skov RL, Paterson GK, Holmes MA, Sabat AJ, Friedrich AW, Köck R, Peters G, Kriegeskorte A. Evaluation of a Modular MultiplexPCR Methicillin-Resistant Staphylococcus aureus Detection Assay Adapted for mecC Detection. J Clin Microbiology. 2013;51:1917-9.

4. Ba X, Harrison EM, Edwards GF, Holden MT, Larsen AR, Petersen A, Skov RL, Peacock SJ, Parkhill J, Paterson GK, Holmes MA. Novel mutations in 
penicillin-binding protein genes in clinical Staphylococcus aureus isolates that are methicillin resistant on susceptibility testing, but lack the mec gene. J Antimicrob Chemother. 2014;69:594-7.

5. Porrero $M C$, Valverde $A$, Fernández-Llario $P$, Díez-Guerrier $A$, Mateos $A$, Lavin S, Cantón R, Fernández-Garayzabal JF, Domínguez L. Staphylococcus aureus carrying mecC gene in animals and urban wastewater, Spain. Emerg Infect Dis. 2014;20:899-901.

6. Benito D, Gómez P, Aspiroz C, Zarazaga M, Lozano C, Torres C. Molecular characterization of Staphylococcus aureus isolated from humans related to a livestock farm in Spain, with detection of MRSA-CC130 carrying mecC gene: A zoonotic case? Enferm Infecc Microbiol Clin. 2016;34:280-5.

7. Basset P, Prod'hom G, Senn L, Greub G, Blanc DS. Very low prevalence of meticillin-resistant Staphylococcus aureus carrying the mecC gene in western Switzerland. J Hosp Infect. 2013;83:257-9.

8. Stegger $M$, Andersen PS, Kearns A, Pichon B, Holmes MA, Edwards G, Laurent $F$, Teale C, Skov R, Larsen AR. Rapid detection, differentiation and typing of methicillin-resistant Staphylococcus aureus harbouring either mecA or the new mecA homologue mecA(LGA251). Clin. Microbiol Infect. 2012;18:395-400.

9. Clinical and Laboratory Standards Institute. Performance standards for antimicrobial susceptibility testing. $24^{\text {th }}$ Informational Supplement M100-S24, 2014. CLSI, Wayne, PA. Available from: https://www.aacc. org/store/books/9200/performance-standards-for-antimicrobialsusceptibility-testing

10. Özel G, Aslan V, Bahar Erdem G, Çağatay M, Sencan I, Mert A. Comparison of oxacillin, cefoxitin, ceftizoxime, and moxalactam disk diffusion methods for detection of methicillin susceptibility in staphylococci. Mikrobiyol Bul. 2011;45:258-65.

11. Cekin Y, Yazisiz H, Kuskucu MA, Ongut G, Baysan BO, Kilinckaya H, Ogunc D, Midilli K, Ozen NS, Colak D. Evaluation of the BD Phoenix system for detection of methicilin resistance in Staphylococcus aureus isolates in comparison to BD GeneOhm MRSA assay. Clin Lab. 2014;60:863-7.

12. Chen J, Luo Y, Zhang S, Liang Z, Wang Y, Zhang Y, Zhou G, Jia Y, Chen L, She D. Community-acquired necrotizing pneumonia caused by methicillinresistant Staphylococcus aureus producing Panton-Valentine leukocidin in a Chinese teenager: case report and literature review. Int J Infect Dis. 2014;26:17-21.

13. Duman $Y$, Tekeroğlu MS, Otlu B. Investigation of the presence of PantonValentine leukocidin and clonal relationship of community and hospital acquired clinical isolates of Staphylococcus aureus. Mikrobiyol Bul. 2013;47:389-400

14. Hu $\mathrm{Q}$, Cheng $H_{\text {, }}$ Yuan $W$, Zeng F, Shang $W$, Tang $D$, Xue W, Fu J, Zhou R, Zhu J, Yang J, Hu Z, Yuan J, Zhang X, Rao O, Li S, Chen Z, Hu X, Wu X, Rao X. Panton-Valentine leukocidin (PVL)-positive health care-associated methicillin-resistant Staphylococcus aureus isolates are associated with skin and soft tissue infections and colonized mainly by infective PVLencoding bacteriophages. J Clin Microbiol. 2015;53:67-72.

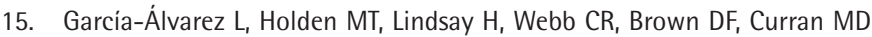
Walpole E, Brooks K, Pickard DJ, Teale C, Parkhill J, Bentley SD, Edwards GF, Girvan EK, Kearns AM, Pichon B, Hill RL, Larsen AR, Skov RL, Peacock SJ, Maskell DJ, Holmes MA. Meticillin-resistant Staphylococcus aureus with a novel mecA homologue in human and bovine populations in the UK and Denmark: a descriptive study. Lancet Infect Dis. 2011;11:595-603.

16. Kerschner $H_{1}$ Harrison $\mathrm{EM}_{1}$ Hartl $\mathrm{R}$, Holmes MA, Apfalter P. First report of mecC MRSA in human samples from Austria: molecular characteristics and clinical data. New Microbes New Infect. 2015;3:4-9.

17. Becker K, Denis 0 , Roisin $S$, Mellmann A, Idelevich EA, Knaack D, van Alen S, Kriegeskorte A, Köck R, Schaumburg F, Peters G, Ballhausen B. Detection of mecA- and mecC-Positive Methicillin-Resistant Staphylococcus aureus (MRSA) Isolates by the New Xpert MRSA Gen 3 PCR Assay. J Clin Microbiol. 2016;54:180-4.

18. Garcia-Garrote $F$, Cercenado E, Marín M, Bal M, Trincado P, Corredoira J, Ballesteros C, Pita J, Alonso P, Vindel A. Methicillin-resistant Staphylococcus aureus carrying the mecC gene: emergence in Spain and report of a fatal case of bacteraemia. J Antimicrob Chemother. 2014;69:45-50.

19. Dermota U, Zdovc I, Strumbelj I, Grmek-Kosnik I, Ribic H, Rupnik M, Golob M, Zajc U, Bes M, Laurent F, Mueller-Premru M. Detection of methicillinresistant Staphylococcus aureus carrying the mecC gene in human samples in Slovenia. Epidemiol Infect. 2015;143:1105-8.

20. Paterson GK, Morgan FJ, Harrison EM, Cartwright EJ, Török ME, Zadoks RN, Parkhill J, Peacock SJ, Holmes MA. Prevalence and characterization of human mecC methicillin-resistant Staphylococcus aureus isolates in England. J Antimicrob Chemother. 2014;69:907-10.

21. Ganesan A, Crawford K, Mende K, Murray CK, Lloyd B, Ellis M, Tribble $\mathrm{DR}$, Weintrob AC. Evaluation for a novel methicillin resistance (mecC) homologue in methicillin-resistant Staphylococcus aureus isolates obtained from injured military personnel. J Clin Microbiol. 2013;51:30735 .

22. Kılıç $A$, Doğan $E$, Kaya $S$, Baysallar M. Investigation of the presence of mecC and Panton-Valentine leukocidin genes in Staphylococcus strains isolated from clinical specimens during seven years period. Mikrobiyol Bul. 2015;49:594-9.

23. Cikman A, Aydin M, Gulhan B, Karakecili $F$, Kurtoglu MG, Yuksekkaya S, Parlak M, Gultepe BS, Cicek AC, Bilman FB, Ciftci IH, Kara M, Atmaca $\mathrm{S}$, Ozekinci T. Absence of the mecC gene in methicillin-resistant Staphylococcus aureus isolated from various clinical samples: The first multi-centered study in Turkey. J Infect Public Health. 2019;12:528-33.

24. Panda RK, Mahapatra A, Mallick B, Chayani N. Evaluation of Genotypic and Phenotypic Methods for Detection of Methicillin Resistant Staphylococcus aureus in a Tertiary Care Hospital of Eastern Odisha. J Clin Diagn Res. 2016;10:19-21.

25. Iraz M, Tekerekoglu MS, Otlu B, Ay S. Comparison of an automated system with four phenotypic methods for the detection of methicillinresistant Staphylococcus aureus. African Journal of Microbiology Research. 2012:6:764-9.

26. Kriegeskorte $A$, Idelevich EA, Schlattmann A, Layer $F$, Strommenger B, Denis 0, Paterson GK, Holmes MA, Werner G, Becker K. Comparison of Different Phenotypic Approaches to Screen and Detect mecC-Harboring Methicillin-Resistant Staphylococcus aureus. J Clin Microbiol. 2017:56.

27. Mencacci A, Montecarlo I, Gonfia F, Moretti A, Cardaccia A, Farinelli S, Pagliochini MR, Giuliani A, Basileo M, Pasticci MB, Bistoni F. Comparison of the BD Phoenix System with the Cefoxitin Disk Diffusion Test for Detection of Methicillin Resistance in Staphylococcus aureus and CoagulaseNegative Staphylococci. J Clin Microbiol. 2009;47:2288- 91.

28. Junkins $A D$, Lockhart $S R$, Heilmann $K P$, Dohrn CL, Von Stein DL, Winokur $\mathrm{PL}$, Doern GV, Richter SS. BD phoenix and Vitek 2 detection of mecAmediated resistance in Staphylococcus aureus with cefoxitin. J Clin Microbiol. 2009;47:2879-82.

29. Kolenda C, Dupieux C, Decousser JW, Larsen AR, Pichon B, Holmes M, Bès $M$, Teale $C$, Dickson $E_{1}$ Hill $R$, Skov R, Kearns A, Laurent F. Comparison of Automated Antimicrobial Susceptibility Testing Systems To Detect mecCPositive Methicillin-Resistant Staphylococcus aureus. J Clin Microbiol. 2017;55:3554-6.

30. van der Mee-Marquet N, Poisson DM, Lavigne JP, Francia T, Tristan A, Vandenesch F, Quentin R, Bertrand X. The incidence of Staphylococcus aureus ST8-USA300 among French pediatric inpatients is rising. Eur J Clin Microbiol Infect Dis. 2015;34:935-42.

31. Demir T, Coplu N, Bayrak H, Turan M, Buyukguclu T, Aksu N, Eksioglu M, Yalcin B, Atakan N, Kilic S, Karahan ZC, Esen B. Panton Valentine leucocidin gene carriage among Staphylococcus aureus strains recovered from skin and soft tissue infections in Turkey. J Antimicrob Chemother. 2012;67:83740.

32. Gülmez D, Sancak B, Ercis S, Karakaya J, Hasçelik G. Investigation of SCCmec types and Panton-Valentine leukocidin in community-acquired and nosocomial Staphylococcus aureus strains: comparing skin and soft tissue infections to the other infections. Mikrobiyol Bul. 2012;46:341-5. 